\title{
Barrier membranes for dental applications: A review and sweet advancement in membrane developments
}

\author{
Rodriguez IA ${ }^{1 * *}$, Selders $\mathrm{GS}^{2 *}$, Fetz $\mathrm{AE}^{2}$, Gehrmann $\mathrm{CJ}^{2}$, Stein $\mathrm{SH}^{3}$, Evensky JA ${ }^{3}$, Green $\mathrm{MS}^{4}$ and Bowlin $\mathrm{GL}^{2}$ \\ ${ }^{1}$ SweetBio Inc., 20 Dudley St., Suite 900, Memphis, TN, 38103, USA \\ ${ }^{2}$ Department of Biomedical Engineering, University of Memphis, 330 Engineering Technology Bldg, 3806 Norriswood Avenue, Memphis, TN, 38152 , USA \\ ${ }^{3}$ Department of Periodontology, University of Tennessee Health Science Center-College of Dentistry, 875 Union Avenue, Memphis, TN 38163 , USA \\ ${ }^{4}$ Department of Periodontology, Tufts University School of Dental Medicine, 1 Kneeland Street, Boston, MA, 02111, USA \\ \#denotes equal contribution
}

\begin{abstract}
Aim: The following review explores the evolution of barrier membranes in oral/periodontal surgical procedures while highlighting the rationale utilized for their development and continued innovative expansion.

Materials and methods: This review is based on systemic reviews (when available) and comparative in vitro, in vivo, and human studies.

Results: Studies show that alveolar ridge/socket preservation following tooth loss/extraction significantly reduces the need for further augmentation at the time of implant placement when compared to unassisted socket healing procedures. With a broad spectrum of barrier membranes clinically available, it is essential to review the advantages and disadvantages of current designs, and those developing within the field.

Conclusion: Advantageous and "sweet" developments, such as conformable moisture-retaining Manuka honey incorporated membranes and those containing prohealing and anti-inflammatory substances for wound healing and infection prevention may be the driving factor compelling surgeons to incorporate ridge preservation into their post-extraction routines.
\end{abstract}

\section{Introduction}

Periodontal disease is a major public health problem; nearly $50 \%$ of adults in the U.S. have some form of periodontitis, with prevalence increasing with age, gender (males $>$ females), and lower socioeconomic status [1]. Periodontitis compromises the dentition to an irreversible point, which can necessitate non-surgical therapy, surgical therapy, or even tooth extraction. If left untreated, periodontitis may affect the course and pathogenesis of several systemic diseases such as diabetes, cardiovascular diseases, and adverse pregnancy outcomes [2-5]. By 2027, it is projected that over 200 million Americans will suffer from edentulism (a potential result of periodontitis), commonly known as partial tooth loss (American College of Prosthodontics 2012). Forty one percent of adults in the U.S. alone have at least one site in need of treatment, and at least $23 \%$ of adults over 65 years of age are edentulous (lacking teeth) [1,6,7]. The consequence of losing a tooth takes many forms; it affects the patient functionally, physiologically, esthetically, psychologically and anatomically via loss of jaw bone through resorption.

Considering the extent of damage at the time of treatment and the great potential for bacterial infection, dental professionals, such as periodontists and oral surgeons, may require barrier membranes for guided bone regeneration (GBR) and/or guided tissue regeneration (GTR) to lessen the destructive effects of the disease process. GTR is a treatment course focused on the reconstruction of the periodontal ligament (PDL) and the restoration of the periodontium to its original form and function. In contrast, GBR is a treatment course focused on maintenance, restoration, or reconstruction of the alveolar ridge bone volume; the treatment may also be necessary to address reconstruction of the peri-implant bone lost as a result of peri-implant disease [8-10]. Both GTR and GBR treatment efforts serve to achieve stability of the blood clot, wound site healing, isolation of the bone- healing site from soft connective tissues, and provide adequate space for bone/ridge healing [11]. GTR and GBR efforts should ideally aim to be consistent with the PASS principles, an established set of 4 biological principles that have been deemed necessary for bone regeneration: 1) Primary wound closure to ensure uninterrupted healing; 2) Angiogenesis to provide blood and nutrient supply as well as delivery of pro-healing cell types; 3) Space maintenance for new bone growth while preventing soft tissue ingrowth; and 4) Stability of wound to include blood clot formation [12]. Use of GTR procedures and results were reported in the early 1980's with the placement of an occlusive membrane between the gingival connective tissue and the alveolar bone to prevent epithelial cell migration into the defect [11]. A similar thought process led to the development of GBR procedures [11].

Correspondence to: Isaac A Rodriguez, SweetBio Inc., 20 Dudley St., Suite 900, Memphis, TN, 38103, USA, Tel: (540) 424-9027; E-mail: isaac@sweetbio.com

Key words: barrier membrane, guided tissue regeneration, guided bone regeneration, periodontal disease, Manuka honey

Received: December 04, 2017; Accepted: January 02, 2018; Published: January 05,2018 
To prevent the related complications associated with hopeless teeth affected by periodontitis, it may be necessary to undergo oral surgery to have these teeth removed. Conservation of the bone height and width, and ultimately, restoration of masticatory function can be accomplished through use of GBR. Either preservation of the alveolar socket or augmentation of the dental ridge is an integral aspect in the future restorative plan for the patient.

Initial steps in the treatment process of a patient with severe periodontitis begins with the diagnosing of all hopeless teeth in need of extraction. It is necessary to evaluate the patient's functionality, esthetics, and their anticipated quality of life with implant dentistry compared to a removable option. Following a treatment plan for extraction, where subsequent ridge preservation is required, the defect site is debrided, and the bone is perforated by the surgeon to create bleeding points prior to implantation of the bone graft and membrane, as shown in Figure 1(A) [13]. Supporting material (commonly bone allo- or autograft) is placed in the void socket to promote bone growth (Figure 1 (B)) while the barrier membrane is implanted sub gingivally over the alveolar ridge to protect the bone growth within the socket, prevent gingival ingrowth, and maintain or improve height and width of the new bone growth (Figure $1(\mathrm{C})$ ). As evident in Figure 1 (A-D), the use of a barrier membrane during a GTR or GBR procedure is critical to the compartmentalization of the connective tissue growth and new bone growth as well as the prevention of a ridge collapse due to socket void. The lack of a barrier membrane to serve as an occlusive and regenerative aid, can lead to complications with extensive epithelial cell migration into the socket, insufficient bone growth, need for further ridge augmentation, or potential inability for future implant placement.

\section{Ideal membrane characteristics from surgeon's per- spective}

Surgeons prefer membranes based on evidence of efficacy, handling properties, and expected goals from the procedure. Expanding on the PASS principles, there are 5 primary surgical objectives for guided bone regeneration: 1) the appropriate and adequate membrane must be chosen; 2) promote healing of primary soft tissues; 3 ) primary closure of the membrane when possible; 4) stabilization of the membrane at the adjacent bone; 5) sufficient long-term healing. Consequently, surgical objectives have driven the need for membranes to not only have these

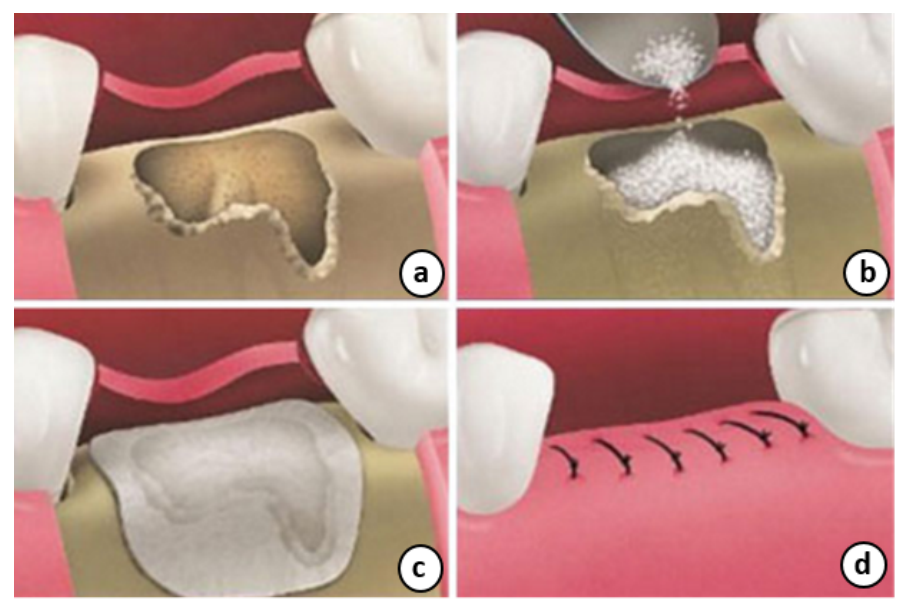

Figure 1. General step-by-step procedural diagram for a GBR/GTR procedure. Treatment begins with a tooth extraction or tooth loss (A), bone graft placement (B), barrier membrane placement for compartmentalization of tissues $(\mathrm{C})$, and closure (when applicable/possible) (D) [13]. traits, but also are biologically inert, appropriately sized, and promote minimal inflammation $[12,14]$.

As it stands with products clinically available today, the ideal membrane characteristics depend on the procedure. For instance, being resorbable is not always desirable. During ridge augmentations, a surgeon may use a titanium mesh or a titanium-reinforced membrane since there are no resorbable membranes that can compare in rigidity and stability. However, fulfilling the needs of surgeons, subsequent key requirements for an ideal barrier membrane include the following capabilities: 1) be cell occlusive; 2) be resorbable while functioning as a barrier; 3) provide sufficient strength to be sutured or tacked, if needed; 4) remain functional if exposed, particularly in cases where primary closure cannot be achieved; 5) allow for conformability to the wound site; 6) compression resistant preventing underlying graft from collapsing (Shu-Tung Li: Collagen Matrix, Inc.).

\section{Expansion of GTR and GBR methods to treat periodontitis}

Not only is the need for a better dental membrane driven by patient/surgical outcome, but is also driven by the increased number of uses/procedures. While socket grafting/preservation is not the current "standard of care", Dr. Gordon Christensen believes that it should be and that all clinicians should embrace using this technique in their practices [15]. This recommendation is supported by evidence highlighted in a meta-analysis by Mardas et al. They concluded that alveolar ridge preservation following tooth extraction significantly reduced the need for further ridge augmentation at the time of implant placement when compared to unassisted socket healing procedures [16]. In the past, general dentists usually only performed preventive care and referred patients needing periodontal treatment to periodontists. However, in the recent decades, there has been a shift in responsibilities taken on by general dentists regarding non-surgical periodontal care. Not only has the number of scaling and root planing procedures tripled in the last 20 years, but the proportion of those procedures being performed by general dentists has increased from $25 \%$ to nearly $90 \%$ [17]. A similar trend was seen for the placement of implants, with general dentists performing nearly $1 / 3$ of all implant placements in 2006. According to Flemmig and Beikler, most dental schools in the USA have incorporated minimal training in implant dentistry at the pre-doctoral level. The anticipated number of general dentists capable and willing to perform relevant socket preservation procedures is expected to increase at a steady rate [17]. With the demonstrated clinical benefit and clinician outlook, it is likely that the field is moving towards implementing ridge/socket preservation as a routine procedure following tooth extraction when restorative considerations are in the treatment plan. It is, therefore, essential, to review and evaluate current clinically available barrier membranes, the advantages and disadvantages of current designs, and those new and developing within the field. The following review explores the evolution of barrier membranes in oral/periodontal surgical procedures while highlighting the rationale utilized for their development and continued innovative expansion.

\section{Non-resorbable barrier membranes}

The widely used non-resorbable barrier membranes are made of polytetrafluoroethylene (PTFE), expanded polytetrafluoroethylene (e-PTFE), titanium (Ti), and titanium-reinforced PTFE (Ti-PTFE) and are commercially available, as seen in Table 1. Various fabrication methods are used to create dense or porous variations of these materials. Because they are biologically inert and chemically stable, PTFE and e-PTFE were appealing first-generation biomaterials for use in GBR 
Table 1. Commercially Available Non-resorbable Synthetic Barrier Membranes.

\begin{tabular}{|c|c|c|}
\hline Product (Company) & Material & Resorption Period \\
\hline BoneShields ${ }^{\circledR}$ (FRIOS) & Titanium & Non-resorbable \\
\hline $\begin{array}{l}\text { Cytoflex }{ }^{\circledR} \text { Tefguard } \\
\text { (Unicare Biomedical) }\end{array}$ & PTFE & Non-resorbable \\
\hline $\begin{array}{l}\text { Cytoplast }^{\mathrm{TM}} \text { Ti- Reinforced } \\
\text { (Osteogenics Biomedical) }\end{array}$ & Ti-PTFE & Non-resorbable \\
\hline Gore-Tex ${ }^{\circledR}\left(\right.$ Gore-Tex $\left.{ }^{\circledR}\right)$ & e-PTFE & Non-resorbable \\
\hline $\begin{array}{l}\text { T-Barrier membrane (B\&B } \\
\text { Dental) }\end{array}$ & Titanium & Non-resorbable \\
\hline TefGen-FD & PTFE & Non-resorbable \\
\hline \multicolumn{3}{|l|}{ (Keystone Dental, Inc.) } \\
\hline Ti-Micromesh (ACE) & Titanium & Non-resorbable \\
\hline Tocksystem (MeshTM) & Titanium & Non-resorbable \\
\hline
\end{tabular}

and GTR procedures. Titanium meshes also prove to still be widely used today [18]. Although PTFE and titanium are non-resorbable and require a second surgery, surgeons continue their use due to their surgical handling properties, malleability, structural rigidity in preventing collapse, and space maintenance for large ridge defects [18].

\section{Advancement of PTFE-based membranes}

Regeneration of bone after trauma is achieved by cells of various tissue compartments including osteocytes, bone marrow cells, cells of endosteum, and osteogenic cells of the periosteum. Specifically, the cells of the periosteum are critical to wound healing progression as they consist of two different layers: an outer fibrous layer which is not osteogenic and an inner layer with osteogenic potential. The osteogenic layer of periosteum consists of production of cells capable of differentiation into osteoblasts and is balanced by the timely loss of osteocytes [19]. Because cells that originate in the periodontal ligament are important for deposition and resorption of alveolar bone, it is important to consider the healing and regeneration of the alveolar bone and periodontal tissue in conjunction. Therefore, it is essential to consider the compartmentalization of the tissues and their respective cell type's regenerative capabilities when developing regenerative therapies. The design of surgical approaches which allow for colonization of bone and periodontal ligament by cells derived from periosteum rather than from the gingiva, are advantageous for adequate bone height growth and maintenance of tissue compartmentalization $[8,19]$.

Early in the progression of GBR research, non-resorbable barrier membranes demonstrated positive healing outcomes due to their ability to occlude unwanted epithelial cells [20,21]. For example, one study by Haney et al. examined the wound stabilizing effect of e-PTFE membranes in supraalveolar periodontal defects in canines [22]. Compared to canines treated only with flap positioning, results showed that bone regeneration was dependent on provisional space, yet exclusion of gingival connective tissue from a defect site did not solely prevent root resorption [22]. In a study by Nyman et al. the use of a millipore filter $(22 \mu \mathrm{m})$ was used as a barrier to prevent gingival tissuederived cells from migrating into the wound and causing epithelization; the use of such filter allowed for improved but suboptimal bone height growth in most cases where the only observation of poor tissue formation was associated with a dislodged filter [8]. Combined, this work demonstrated a need in GTR technologies to improve bone regeneration beyond the current barrier membrane paradigm. New techniques were developed which utilized a combination of non-resorbable barrier membranes and bone grafts [23-26]. Vital bone formation showed significant increase with the placement of a membrane and graft, thus decreasing the risk of bone resorption and increasing positive healing outcomes.
Synthetic non-resorbable membranes have had various advances in PTFE membrane development. The use of e-PTFE helps promote tissue growth of the socket flap compared to the use of less porous PTFE membranes. Increased porosity of e-PTFE membranes causes an increase in bacteria migration and tissue ingrowth within the porous membrane. Another PTFE membrane known as non-expanded and dense/non-porous PTFE (n-PTFE) can be used; n-PTFE has a smooth outward face which can prevent tissue ingrowth, but this can ultimately lead to poor socket flap adhesion and increases the possibility of tissue dehiscence [27]. Another method used to improve GBR further includes the implementation of more rigid Ti-ePTFE membranes. Figure 2 (AF) displays treatment of a Seibert class III alveolar ridge augmentation with BioOSS bone graft and a non-resorbable Ti-reinforced e-PTFE membrane (Cytoplast ${ }^{\mathrm{Tw}}$ ) [28]. Ti-reinforced e-PTFE's increased mechanical integrity can be beneficial as it enhances bone graft stabilization while occluding soft tissue [29-31]. Such studies base their success solely on GBR without regard to GTR.

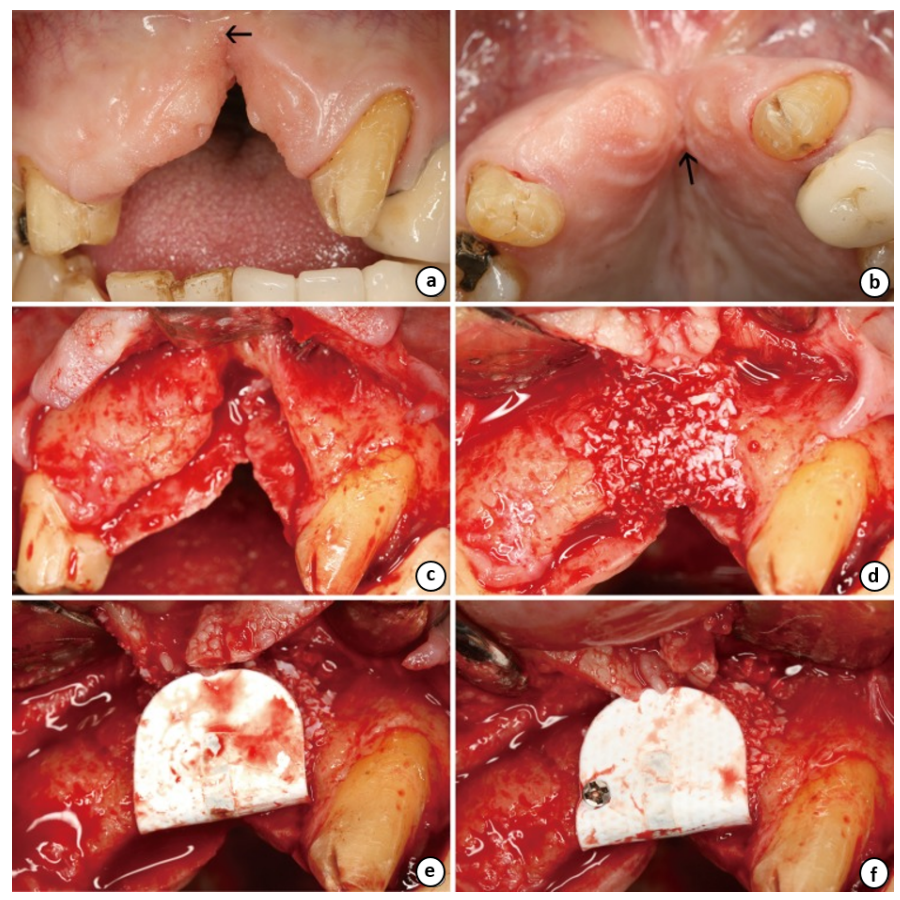

Figure 2. Patient Seibert class III alveolar defect in the anterior maxillary arch (A, B) Horizontal and vertical deficiencies were visualized following a flap reflection (C). Bone grafting material (BioOSS) was placed (D) prior to the application of a non-resorbable synthetic membrane (Cytoplast ${ }^{\mathrm{TM}}$ ) (E) which was secured in place with a titanium screw $(\mathrm{F})$ Reprinted with permission: http://creativecommons.org/licenses/by-nc/3.0/.

\section{Titanium meshes}

Porous titanium meshes, first used in 1969 and also non-resorbable, offer benefits which are especially practical for clinical use. Titanium meshes offer substantial increased surgical malleability, improved space management, and prevention of collapse (leading to sufficient bone growth), and high strength while being lightweight. Titanium can withstand high temperatures (e.g. sterilization prior to implantation) and is corrosion resistant when easily passivated. Its low density allows for conformational flexibility, enabling bending and contouring of the membrane to the bony defect/ridge shape [18]. In addition to its wear and contouring characteristics, the macroporosity of titanium meshes is advantageous for the maintenance of the blood supply as well as enhancing wound stability and tissue integration [18]. 


\section{Disadvantages of non-resorbable membranes}

Although PTFE, e-PTFE, and Ti-PTFE membranes illustrate positive healing outcomes in GBR, there are several disadvantages associated with their use. Non-resorbable membranes require surgical removal after sufficient bone regeneration to minimize an inflammatory response. Aside from risks associated with additional surgeries, there exists a lack of consensus or standardization on the appropriate time to remove membranes post-implantation. Typically, GTR membranes remain in the wound site between 4-6 weeks while GBR membranes should remain longer to support bone growth over several months with the final implantation time being dependent on the surgeon's discretion. Early removal can result in bone resorption while late removal increases the risk of microbial infections [32]. PTFE membranes have also been shown to decrease collagen production and Glycosaminoglycan (GAG) accumulation which indicates that non-resorbable membranes do not aid in soft tissue closure and may slow healing of the overlying tissue [33]. Additionally, titanium-based meshes can cause continual soft tissue irritation due to perforation of the gingival tissue upon accidental exposure of the sharp edges of the membrane, and although they can enhance tissue integration, the removal of such meshes can be detrimental to soft tissue growth [18]. Therefore, even though non-resorbable membranes improve hard tissue regeneration, they are of little to no benefit for soft tissue regeneration (i.e. GTR), especially long-term. Consequently, product development has shifted in recent years to resorbable, synthetic, and natural membranes which aim to improve both GBR and GTR to avoid complications associated with the removal of the membrane, ultimately re-injuring the site.

\section{Resorbable synthetic barrier membranes}

In an effort to overcome the need for a second operation for membrane removal, barrier membranes are also constructed from biodegradable materials. Using resorbable synthetic membranes additionally decreases the need for surgical intervention from inflammation of membranes as well [34].

\section{Advantages of resorbable membranes}

The need for developing resorbable membranes as an alternative to non-resorbable membranes primarily arose to avoid an additional surgery for removal [35] [11]. Due to their integration within the tissue, these membranes require the addition of biocompatibility while maintaining their shape and material properties for weeks while in the wound site. Currently, clinicians use membranes made of Poly-Lactic Acid (PLA) and Poly-Glycolic Acid (PGA), and various blends of these polymers made commercially available under the names in Table 2. In clinical trials comparing use of Atrisorb membranes with various debridement methods, the Atrisorb trials showed increases in clinical attachment level of gingival tissues $(3.61 \mathrm{~mm}$ vs. $1.64 \mathrm{~mm}$ ) and also in growth of alveolar bone $(2.76 \mathrm{~mm}$ vs. $1.42 \mathrm{~mm})$ over the span of a year [36].

\section{Mechanical and chemical properties}

Resorbable synthetic membranes have a wide range of tensile strengths that depend on the ratio of polymers used such as PLA and PGA. Other factors such as the extent of crosslinking can be used to increase tensile strength at the cost of prolonging the degradation timeline. The variation in membrane composition and treatment leads to a wide range of tensile strengths from 40-140 MPa for PLA and PGA scaffolds [37]. In comparison, the average tensile strength of non-resorbable
Table 2. Commercially Available Resorbable Synthetic Barrier Membranes.

\begin{tabular}{|c|c|c|}
\hline Product (Company) & Material & Resorption Period (months) \\
\hline Guidor ${ }^{\circledR}$ (Sunstar) & $\begin{array}{l}\text { PLA } \\
\text { (Polylactic Acid) }\end{array}$ & $1.5-2$ \\
\hline Resorb X® (KLS Martin) & $\begin{array}{l}\text { PDLLA } \\
\text { (Poly-DL-Lactic Acid) }\end{array}$ & $1.5-2$ \\
\hline $\begin{array}{l}\text { Cytoflex Resorb }{ }^{\circledR} \text { (Unicare } \\
\text { Biomedical) }\end{array}$ & $\begin{array}{l}\text { PLGA } \\
\text { (Poly-Lactic-Glycolic Acid) }\end{array}$ & 4 \\
\hline Resolute ${ }^{\circledR}($ Gore $($ ) & $\begin{array}{l}\text { PGA-TMC } \\
\text { (Polyglycolic Acid } \\
\text { Trimethylene Carbonate) }\end{array}$ & $4-6$ \\
\hline Epi-Guide ${ }^{\circledR}$ (Curasan, Inc.) & $\begin{array}{l}\text { PDLLA } \\
\text { (Poly-DL-Lactic Acid) }\end{array}$ & $6-12$ \\
\hline Atrisorb (Tolmar) & $\begin{array}{l}\text { P(DL)LA - NMP } \\
\text { (Poly-DL-Lactic Acid) }\end{array}$ & $9-12$ \\
\hline Inion ${ }^{\mathrm{TM}}$ GTR (Inion) & $\begin{array}{l}\text { PLDLGA-TMC } \\
\text { (Poly-LD-Lactic-Glycolic } \\
\text { Acid Trimethylene } \\
\text { Carbonate) }\end{array}$ & $12-24$ \\
\hline Vivosorb $₫($ Polyganics) & $\begin{array}{l}\text { PDLLCL } \\
\text { (Poly-DL-Caprolactone) }\end{array}$ & 16 \\
\hline
\end{tabular}

synthetic membranes such as e-PTFE has values around $100 \mathrm{MPa}$ [38]. In contrast, natural degradable polymers, such as porcine membranes, have much lower tensile strength within the range of 4-5 $\mathrm{MPa}$ [39].

Biologically resorbable membranes, such as PLA and PGA, are broken down by proteolytic enzymes from the polymorphonuclear (PMN) cells into lactic acid or glycolic acid which is excreted through the kidney or used in the citric acid cycle as a pyruvate in metabolism. These cells are also key members of the inflammatory response and often generate harmful oxidative species when breaking down synthetic membranes. Studies have shown that there is a correlation between material choices and the duration and magnitude of the PMN response [40]. This inflammatory response at the membrane site can cause decoherence in tissue integration and may even lead to failure of the implanted device over time. A material choice which minimizes this inflammatory response involves the use of decellularized bovine bone as a guiding membrane. These biologically based matrices provide the decrease in immune response necessary to ensure proper tissue healing environments but also may lack the osteoconductivity that synthetic membranes possess [41].

\section{Resorbable natural barrier membranes}

The majority of natural resorbable membranes are composed of collagen, either bovine or porcine in origin. Type I collagen is most commonly used since it is the most prevalent of the collagens comprising about $25 \%$ of the body's proteins, $80 \%$ of connective tissue proteins, and $90 \%$ of mineralized organic bone extracellular matrix $[42,43]$. Type I and III collagen membranes are well accepted by the Food and Drug Administration (FDA) for their biocompatibility as evident in the number of clinically available membranes on the market (Table 3).

\section{Clinical effectiveness of collagen membranes}

Since the late 1990's, the effectiveness of collagen (resorbable) and e-PTFE (non- resorbable) membranes has been studied and the membranes compared extensively. These studies have primarily reported that both collagen and e-PTFE membranes improve bone regeneration around implants. Since collagen is more biocompatible and does not require a secondary surgery, it can be used as a valid alternative to non-resorbable e-PTFE membranes [44,45]. In vitro studies conducted by Alpar et al. compared the cytocompatibility of resorbable (synthetic- PLA; natural- collagen) and non-resorbable 
Table 3. Commercially Available Resorbable Natural Barrier Membranes.

\begin{tabular}{|c|c|c|}
\hline Product (Company) & Material & Resorption Period (months) \\
\hline $\begin{array}{l}\text { CollaPlug }{ }^{\circledR}(\text { Zimmer } \\
\text { Dental) }\end{array}$ & Type I bovine collagen & 0.5 \\
\hline BioMend ${ }^{\circledR}($ Zimmer Dental $)$ & Type I bovine collagen & 2 \\
\hline Healiguide $^{\mathrm{TM}}$ (Encoll) & Type I collagen & $1-3$ \\
\hline $\begin{array}{l}\text { GenDerm } \\
\text { (Genius biomaterials) }\end{array}$ & Type I bovine collagen & 3 \\
\hline $\begin{array}{l}\text { Surgidry Dental F } \\
\text { (TechoDry Liofilizados } \\
\text { Médicos Ltda Brazil) }\end{array}$ & Type I bovine collagen & 3 \\
\hline $\begin{array}{l}\text { conFORM }{ }^{\mathrm{TM}} \\
\text { (ACE Surgical Supply Co., } \\
\text { Inc.) }\end{array}$ & Type I bovine collagen & $3-4$ \\
\hline $\begin{array}{l}\text { Mem-Lok }{ }^{\circledR} \text { Pliable } \\
\text { (BioHorizons) }\end{array}$ & Type I porcine collagen & $3-4$ \\
\hline 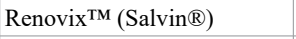 & Type I porcine collagen & $3-4$ \\
\hline $\begin{array}{l}\text { creos }^{\mathrm{TM}} \text { xenoprotect (Nobel } \\
\text { Biocare }(\mathbb{R})\end{array}$ & $\begin{array}{l}\text { Porcine collagen and } \\
\text { elastin }\end{array}$ & $3-4$ \\
\hline $\begin{array}{l}\text { EzCure }^{\mathrm{TM}} \text { (Biomatlante } \\
\text { Biologic Solutions) }\end{array}$ & $\begin{array}{l}\text { Type I and III porcine } \\
\text { collagen }\end{array}$ & $3-6$ \\
\hline $\begin{array}{l}\text { BioMend } ₫ \text { Extend (Zimmer } \\
\text { Dental) }\end{array}$ & Type I bovine collagen & $4-5$ \\
\hline $\begin{array}{l}\text { OSSIX }{ }^{\circledR} \text { PLUS (Datum } \\
\text { Dental) }\end{array}$ & Type I porcine collagen & $4-6$ \\
\hline Kontour $^{\mathrm{TM}}$ (Implant Direct) & Type I porcine collagen & $4-6$ \\
\hline $\begin{array}{l}\text { Mem-Lok } ₫ \text { Pericardium } \\
\text { (BioHorizons) }\end{array}$ & $\begin{array}{l}\text { Allograft of human } \\
\text { pericardium tissue }\end{array}$ & $4-6$ \\
\hline $\begin{array}{l}\text { BioGide }{ }^{\circledR}(\text { Geistlich } \\
\text { Biomaterials } \\
\text { Switzerland) } \\
\end{array}$ & $\begin{array}{l}\text { Type I and III porcine } \\
\text { collagen }\end{array}$ & 6 \\
\hline $\begin{array}{l}\text { GENOSS Collagen } \\
\text { Membrane (GENOSS) }\end{array}$ & Type I bovine collagen & 6 \\
\hline $\begin{array}{l}\text { Osteogenics Vitala Collagen } \\
\text { Membrane }\end{array}$ & Porcine pericardium & 6.5 \\
\hline BioSorb $^{\mathrm{TM}}$ (3M ESPE) & Type I bovine collagen & $6-9$ \\
\hline $\begin{array}{l}\text { Mem-Lok }{ }^{\circledR} \mathrm{RCM} \\
\text { (BioHorizons) }\end{array}$ & Type I bovine collagen & $6-10$ \\
\hline $\begin{array}{l}\text { Cytoplast }{ }^{\mathrm{TM}} \text { (Osteogenics } \\
\text { Biomedical) }\end{array}$ & RTM collagen & $6-10$ \\
\hline $\begin{array}{l}\text { ACM6 (ACE Surgical } \\
\text { Supply Co., Inc.) }\end{array}$ & Type I bovine collagen & $6-10$ \\
\hline CollaGuide $^{\mathrm{TM}}$ (Curasan, Inc.) & Type I bovine collagen & 8 \\
\hline AlloDerm ${ }^{\circledR}$ GBR (LifeCell) & $\begin{array}{l}\text { Collagen-based acellular } \\
\text { tissue construct }\end{array}$ & Degradation undisclosed \\
\hline $\begin{array}{l}\text { BioXclude }{ }^{\circledR} \text { (Snoasis } \\
\text { Medical) }\end{array}$ & $\begin{array}{l}\text { Allograft of human amnion } \\
\text { chorion tissue, dehydrated } \\
\text { placenta }\end{array}$ & Degradation undisclosed \\
\hline
\end{tabular}

(e-PTFE) membranes in fibroblast and osteoblast-like cell cultures. Results indicated that the e-PTFE and PLA membranes induced slight to moderate cytotoxic reactions while collagen membranes were very cytocompatible and possess greater potential to be integrated well into the connective tissue (Alpar 2000). A separate in vitro study performed by Kasaj et al. examined three commercially available collagen membranes and three non-resorbable PTFE membranes concluding that resorbable membranes are more suitable to stimulate cellular proliferation when compared to non-resorbable membranes [46]. Because of these benefits, the dental field is moving towards the use of natural, protein-based membranes where collagen is the primary protein of interest, evident by collagen-based barrier membranes currently comprising more than $3 / 4$ of the market. Collagen, with its triple helical structure, is a key component of both bone and soft tissues and its organization is responsible for structural integrity and mechanical strength of tissues, making it particularly biologically relevant to socket grafting and GTR efforts as these are the tissues dental clinicians are hoping to functionally regenerate[47]. Collagen-based membranes are considered bioactive as they provide binding sites for migrating woundhealing cells which ultimately results in microenvironmental cues for promoting tissue regeneration, fostering a hospitable environment following surgical intervention $[47,48]$. In addition to the advantages of its composition, the effectiveness of collagen membranes can be enhanced when used in combination with a bone graft. Figure $3(\mathrm{~A}-\mathrm{F})$ illustrates the clinical benefit ( 9 months postoperative) of use of bone grafting material (BioOss) and a membrane (AlloDerm ${ }^{\circ}$ GBR) to treat a class I ridge defect. The patient experienced significant hard and soft tissue growth [49]. Clinical studies have shown the widely accepted use of a collagen barrier membrane with a bone graft significantly improves clinical parameters such as preserving alveolar crest height and shape, probing pocket depth, attachment, defect depth, and gingival recession compared to resorbable membranes [50,51].

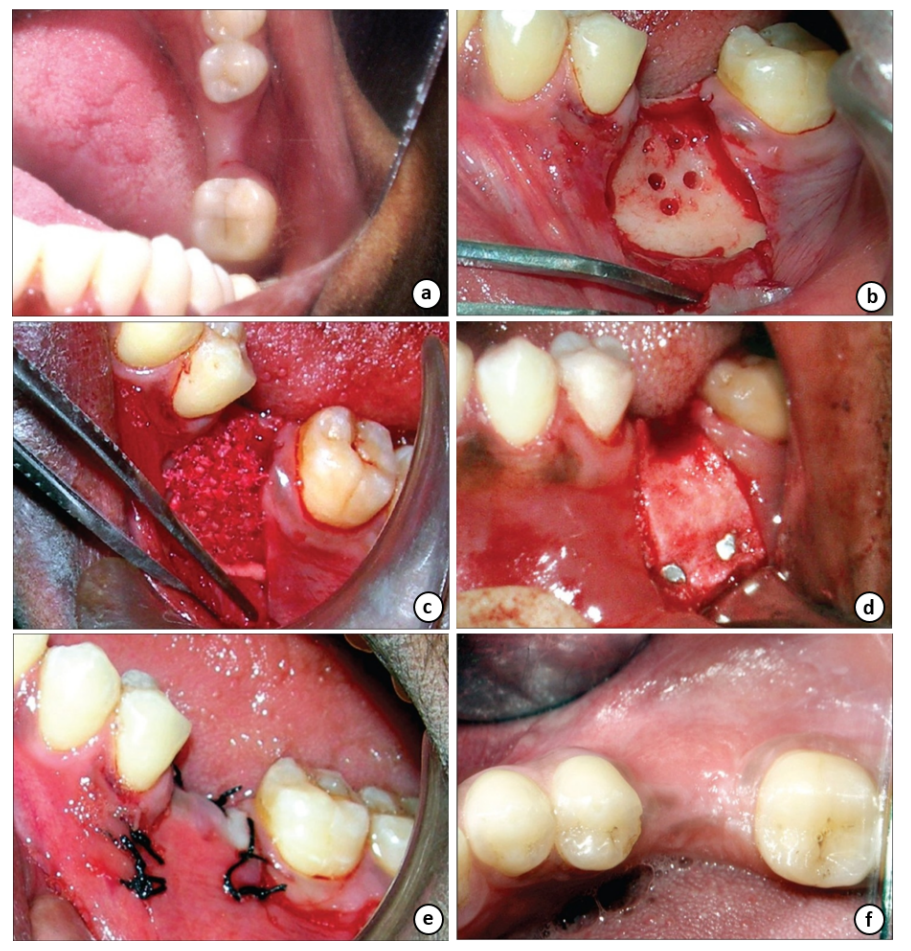

Figure 3. Visual diagram of a class I ridge defect procedure. Patient Seibert class I ridge defect $(A, B)$ treated with BioOSS bone graft $(C)$ and an AlloDerm ${ }^{\circledR}$ GBR membrane (D), secured with silk sutures (E) for ridge restoration and augmentation, with significant hard and soft tissue growth at 9 months postoperative (F) Reprinted with permission: http// creativecommons.org/licenses/by-nc/3.0

\section{Emerging natural materials in barrier membranes}

Recently, a case report demonstrated the potential of complex biologic materials to function as barrier membranes. BioXclude, a thin membrane derived from human placenta, has recently been adopted and is commercially available. The resorbable membrane contains angiogenic growth factors as well as interleukins and tissue inhibitors of metalloproteinases.

This membrane has shown in vitro to increase the migration of human mesenchymal stem cells and in vivo to recruit mesenchymal progenitor cells. In the clinic, a case study was performed in which the membrane was successfully implanted in a patient and shown to positively influence the healing outcome. Another study compared BioXclude to BioGide, both membranes seen below in Table 3, where BioXclude was observed to better minimize gingival recession [52]. 
The success of this biologic-derived membrane in vitro, in vivo, and in case studies illustrates the potential to further develop more complex, naturally-derived barrier membranes that have the ability to enhance both hard and soft tissue regeneration.

\section{Hybrid and multiphasic barrier membranes}

Although resorbable synthetic and natural barrier membranes eliminated the need for the second surgery, they still do not fully address the much-needed acceleration of the healing process, mechanical integrity, or the administration of an antibiotic [53]. A common and underlying limitation to rapidly degrading polymeric membranes is the formation of immature tissue as a result of the disappearance of the membrane before true tissue development and/or remodeling [53,54]. As such, both hybrid and multiphasic membranes have been under development for periodontal tissue engineering. Such membranes types allow for the combination of multiple polymers which in turn allows more tailored degradation timelines.

\section{Multiphasic membranes}

Multiphasic membranes are designed in phases (or layers) in order to meet the various criteria of the periodontal tissue types as well as fulfilling the barrier function. Multiphasic membranes vary in fabrication, structure, porosity, organization, and composition [54]. The challenge of multiphasic membranes is to achieve suitable assembly of the multiple phases together such that handling, and implantation will not cause destruction or disassembly of the template construct [54]. Pertaining particularly to periodontal tissue engineering, the development of multiphasic membranes addresses the need to enhance the wound healing process, as well as, allow sufficient space for new bone formation [54]. Essentially, the multiphasic (biphasic, triphasic, etc.) membranes attempt to incorporate into one, the advantages of synthetic and biological resorbable polymeric membranes loaded with bioactive agents to better mechanically stabilize the wound and promote accelerated regeneration of the periodontal tissue.

Some membranes have been developed to be used along with growth factors, an example being a PLA and alginate hybrid combination membrane, which is then loaded with transforming growth factor beta (TGF-beta), for long term growth factor release [55]. A resorbable human demineralized membrane (RHDM) has been explored for use as a barrier membrane [14].

Periodontal tissue engineering constructs tend to include the incorporation of cells, often stem or progenitor cells, relying on the appropriate in vivo differentiation of the cells into the specific cell types in the surrounding tissue [54]. Some multiphasic approaches have utilized the manufacturing of membranes via three-dimensional wax printing and subsequent seeding with cells [54]. A compartmentalized biphasic membrane was fabricated by electrospinning Polycaprolactone and seeded with PDL cell sheets. Further, the membrane was enhanced by coating with calcium phosphate to promote the osteoconductive nature of the PDLs in vivo [54]. A triphasic membrane has been developed with a $10 \%$ (wt\%) hydroxyapatite-polycaprolactone (HAPCL) scaffold using three-dimensional printing. Other material types under investigation include the triphasic nano-carbonated hydroxyapatite/collagen/PLA membrane and Atrisorb, produced by Atrix Laboratories Inc., is applied in a liquid fashion and has been successfully used as a barrier membrane [56,57]. The list goes on, but the concept remains the same. Researchers are trying to engineer the optimal hybrid combination of polymers, degradation rate, hydrophilicity, antimicrobial properties, and cell type for the barrier membrane.

\section{Anti-infective membranes}

Infection contributes largely to the success or failure of barrier membranes, and is often associated with the membrane as a result of the body's natural relentless foreign body response or simply because of a bacterial presence at the wound site. Infection is therefore considered the greatest reason for the clinical failure of barrier membranes $[58,59]$. As such an issue is likely to occur, and is often unavoidable, hybrid membranes and drug-coated anti-infective biomaterials have been examined for barrier applications. By incorporating bioactive molecules or anti-infective agents in barrier membranes, the infection can be avoidable or treatable via the membrane. Additionally, the antimicrobial effects of incorporated drugs in membranes can both accelerate the wound healing process, as well as, ultimately improve the regenerative outcome $[53,55]$. Bacteria present in the oral cavity and usually the root cause of infections from a GTR procedure include Porphyromonas gingivalis, Aggregatibacter actinomycetemcomitans, and Streptacoccus mutans [60].

Drugs used in barrier membranes, such as Metronidazole (MNA) and N-methylpyrrolidone (NMP) have selective activity against bacteria and have been used to treat bacterial infections for nearly fifty years [55,59]. Xue and colleagues performed a study that analyzed an MNA loaded PCL/Gelatin electrospun membrane for local MNA delivery for GTR [59]. As a means of incorporating an anti-infective drug into the membranes and monitor the drug's release, MNA was combined with slowly degrading PCL and gelatin (to mediate the degradation rate) then electrospun. Results of the study indicated that the membranes containing greater than 5\% MNA exhibited obvious antibacterial activity by preventing bacterial growth.

The membranes did not exhibit any cytotoxic effects [59]. PCL, PLA and PLGA-based barrier membranes have also been loaded with MNA for anti-infective GTR solutions [55]. Even more clinically relevant, a study was conducted to compare PLGA membranes (Inion ${ }^{\mathrm{st}}$ ) loaded with NMP to the e-PTFE gold standard $\left(\right.$ Gore-Tex $\left.{ }^{\circ}\right)$. Both chemical vapor deposition and dip coating methods were used to load the NMP onto the Inion ${ }^{\text {Tw }}$ membranes. The results of the study determined that the NMP-loaded membranes were just as equally effective as the Gore$\mathrm{Tex}^{\otimes}$, and their resorbable nature required no surgical removal, unlike the Gore-Tex ${ }^{\circ}$. Chemical vapor deposition produced a more favorable result, with slower, controlled NMP release, rather than the rapid release observed by the dip-coated NMP membranes [53].

\section{"Sweet" Manuka honey advancements for barrier mem- branes}

Honey, as a substance, is viscous, osmotic, and hygroscopic in nature which are crucial properties for maintenance of moisture at the wound site, wound fluid exudation, and providing a physical protective barrier over the wound, all of which are associated with wound healing $[61,62]$. Leveraging the viscous and hygroscopic (moistureretaining) properties of the "sweet" ingredient, Manuka honey (a monofloral honey made from the nectar of the Manuka tea tree, Leptospermum scoparium, and Manuka flower native to New Zealand and southeastern Australia), a dental barrier membrane was developed by SweetBio, Inc. They are the first company to explore this natural ingredient in the field of dental surgery. SweetBio, Inc.'s first product is a resorbable collagen-derived, Manuka honey-incorporated barrier membrane for GTR procedures. SweetBio's product is not yet FDA cleared, however preliminary results indicate the product's potential to have conformable handling properties and a favorable effect on wound healing in GTR procedures. 
Recently, the development of antibiotic resistant strains of bacteria has become a threatening reality of clinical procedures, especially related to barrier membranes. Researchers have begun to revert to medicinal plant therapies for a remedy to the ever-growing issue. Sticky, sweet, and viscous, Manuka honey has proven to be resistant to nearly 60 different types of Gram-negative and Gram-positive bacteria including, but not limited to, Staphylococcus aureus, Helicobacter pylori, Escherichia coli, and Methicillin-resistant Staphylococcus aureus (MRSA) [61-64]. Its antibacterial characteristics stem from its hygroscopic nature and low $\mathrm{pH}(3.2-4.5)$, both of which inhibit bacterial growth $[61,62]$. Additionally, the low $\mathrm{pH}$ of Manuka honey contributes to the process of angiogenesis, which is essential for tissue regeneration and integration [65,66]. Honey also generates hydrogen peroxide $\left(\mathrm{H}_{2} \mathrm{O}_{2}\right)$ as glucose is broken down, which is primarily responsible for its natural antimicrobial effects [62]. Because of the microenvironment honey provides, it assists in the regulation and recruitment of cells responsible for early wound repair, such as neutrophils and monocytes [62]. Additionally, particularly unique to Manuka honey, is the presence of high amounts of methylglyoxal (MGO) which produce a non-peroxide antibacterial effect, ultimately preventing adjacent tissue damage and promoting tissue regeneration $[60,61,64]$. This MGO content is described as the Unique Manuka Factor (UMF) and has become a standard measurement (rating scale) of the non-peroxide antibiotic activity of the honey, increasing with increased antibiotic activity $[60,61]$.

Manuka honey has been used for a variety of other applications such as treatment for ulcerative colitis, oral rinses for plaque reduction, open dermal wounds, burn wounds, and even as an anti-proliferative agent against cancer cells [61,67-69]. This "sweet" ingredient has been incorporated into clinically available products, such as Derma Sciences Inc. MediHoney which is often used for burns, ulcers, and wound dressings, and has been known to fight infections, including MRSA and Pseudomonas aeruginosa $[61,67,68]$. Specifically related to the oral cavity and periodontal membranes, is Manuka honey's ability to fight bacterial infections and biofilms from bacteria species Porphyromonas gingivalis, Aggregatibacter actinomycetemcomitans, and Streptacoccus mutans, three very aggressive oral bacteria that can affect the success or failure of dental barrier membranes [60,63]. Considering the numerous advantageous properties of Manuka honey, the use of this material as an ingredient in the development of dental barrier membranes should not be ignored.

\section{Conclusion}

With the first wave of the baby boomer generation reaching the age where implants may become the best treatment option for edentulism, it is inevitable that the number of grafting procedures will continue to rise. It is critical to consider the benefits of socket/ridge preservation and the use of barrier membranes when treating and planning tooth extractions. The clinician's choice of barrier membrane is determined by the type of procedure and the desired outcome, necessitated by the state of the site following tooth extraction. Although there is a broad spectrum of commercially available membranes to meet a variety of surgeon's needs, the expansion into conformable Manuka honey incorporated membranes and those containing pro- healing and antiinflammatory substances could have additional benefits including moisture retention, wound healing and infection prevention. These advantageous developments may compel surgeons to incorporate socket/ridge preservation into their post-extraction routine, particularly if this new generation of membranes can be offered to patients at a similar cost and with improved patient outcomes.

\section{Competing interests}

Drs. Rodriguez and Bowlin have an equity interest in SweetBio, Inc. and are co-inventors of the patent-pending technology. Dr. Rodriguez is an employee of SweetBio, Inc. Selders, Fetz, Gehrmann, Dr. Stein, Dr. Evensky, and Dr. Green have no conflicts of interest or financial ties to disclose.

\section{Funding information}

There are no financial disclosures.

\section{References}

1. Eke PI, Dye BA, Wei L, Thornton-Evans GO, Genco RJ, et al. (2012) Prevalence of periodontitis in adults in the United States: 2009 and 2010. J Dent Res 91: 914-920. [Crossref]

2. Li X, Kolltveit KM, Tronstad L, Olsen I (2000) Systemic diseases caused by oral infection. Clin Microbiol Rev 13: 547-558. [Crossref]

3. D'Aiuto F, Graziani F, Tetè S, Gabriele M, Tonetti MS (2005) Periodontitis: from local infection to systemic diseases. Int J Immunopathol Pharmacol 18: 1-11. [Crossref]

4. Holmstrup P, Poulsen AH, Andersen L, Skuldbøl T, Fiehn NE (2003) Oral infections and systemic diseases. Dent Clin North Am 47: 575-598. [Crossref]

5. Engebretson SP, Lalla E, Lamster IB (1999) Periodontitis and systemic disease. $N Y$ State Dent J 65: 30-32. [Crossref]

6. Emami E, de Souza RF, Kabawat M, Feine JS (2013) The impact of edentulism on oral and general health. Int J Dent 2013: 498305. [Crossref]

7. Wu B, Liang J, Plassman BL, Remle C, Luo X (2012) Edentulism trends among middle-aged and older adults in the United States: comparison of five racial/ethnic groups. Community Dent Oral Epidemiol 40:145-153. [Crossref]

8. Nyman S, Gottlow J, Karring T, Lindhe J (1982) The regenerative potential of the periodontal ligament. An experimental study in the monkey. J Clin Periodontol 9: 257265. [Crossref]

9. Gottlow J, Nyman S, Karring T, Lindhe J (1984) New attachment formation as the result of controlled tissue regeneration. J Clin Periodontol 11: 494-503. [Crossref]

10. Gottlow J, Nyman S, Lindhe J, Karring T, Wennström J (1986) New attachmen formation in the human periodontium by guided tissue regeneration. Case reports. $J$ Clin Periodontol 13: 604-616. [Crossref]

11. Pellegrini G, Pagni G, Rasperini G (2013) Surgical approaches based on biological objectives: GTR versus GBR techniques. Int J Dent 2013. [Crossref]

12. Wang HL, Boyapati L (2006) "PASS" principles for predictable bone regeneration. Implant Dent 15: 8-17. [Crossref]

13. Ramsey A (2014) "What Is A Membrane? Do I Need One For My Implant Bone Graft? My Membrane Fell Out/Sticking Out and Exposed.” Ramsey A. Amin, DDS, 30 Sept.

14. Bubalo M, Lazić Z, Matić S, Tatić Z, Milović R, et al. (2012) The impact of thickness of resorbable membrane of human origin on the ossification of bone defects: a pathohistologic study. Vojnosanit Pregl 69: 1076-1083. [Crossref]

15. Christensen GJ (2012) Is socket grafting standard of care? Dental Economics 102(7).

16. Mardas N, Trullenque-Eriksson A, MacBeth N, Petrie A, Donos N (2015) Does ridge preservation following tooth extraction improve implant treatment outcomes: a systematic review. Clin Oral Implants Res. 26:180-201. [Crossref]

17. Flemmig TF, Beikler T (2013) Economics of periodontal care: market trends, competitive forces and incentives. Periodontol 2000 62: 287-304. [Crossref]

18. Rakhmatia YD, Ayukawa Y, Furuhashi A, Koyano K (2013) Current barrier membranes: titanium mesh and other membranes for guided bone regeneration in dental applications. J Prosthodont Res 57:3-14. [Crossref]

19. Melcher AH (1976) On the repair potential of periodontal tissues. $J$ Periodontol 47 256-260. [Crossref]

20. Kersten BG, Chamberlain AD, Khorsandi S, Wikesjö UM, Selvig KA, et al. (1992) Healing of the intrabony periodontal lesion following root conditioning with citric acid and wound closure including an expanded PTFE membrane. J Periodontol 63: 876882. [Crossref] 
21. Ohnishi H, Fujii N, Futami T, Taguchi N, Kusakari H, et al. (2000) A histochemical investigation of the bone formation process by guided bone regeneration in rat jaws. Effect of PTFE membrane application periods on newly formed bone. $J$ Periodontol 71:341-352. [Crossref]

22. Haney JM, Nilvéus RE, McMillan PJ, Wikesjö UM (1993) Periodontal repair in dogs: expanded polytetrafluoroethylene barrier membranes support wound stabilization and enhance bone regeneration. J Periodontol 64:883-890. [Crossref]

23. Anderegg CR, Martin SJ, Gray JL, Mellonig JT, Gher ME (1991) Clinical evaluation of the use of decalcified freeze-dried bone allograft with guided tissue regeneration in the treatment of molar furcation invasions. J Periodontol 62:264-268. [Crossref]

24. Tarnow DP, Wallace SS, Froum SJ, Rohrer MD, Cho SC (2000) Histologic and clinical comparison of bilateral sinus floor elevations with and without barrier membrane placement in 12 patients: Part 3 of an ongoing prospective study. Int $J$ Periodontics Restorative Dent 20:117-25. [Crossref]

25. Jardini MA, De Marco AC, Lima LA (2005) Early healing pattern of autogenous bone grafts with and without e-PTFE membranes: a histomorphometric study in rats. Oral Surg Oral Med Oral Pathol Oral Radiol Endod 100: 666-673. [Crossref]

26. Donos N, Kostopoulos L, Karring T (2002) Alveolar ridge augmentation using a resorbable copolymer membrane and autogenous bone grafts. Clinical Oral Implants Research 13:203-213. [Crossref]

27. Carbonell JM, Martín IS, Santos A, Pujol A, Sanz-Moliner JD, et al. (2014) Highdensity polytetrafluoroethylene membranes in guided bone and tissue regeneration procedures: a literature review Int J Oral Maxillofac Surg. 43:75-84. [Crossref]

28. Jung G-U, Pang E-K, Park C-J (2014) Anterior maxillary defect reconstruction with a staged bilateral rotated palatal graft. J Periodontal Implant Sci.44:147-155. [Crossref]

29. Canullo L, Malagnino VA (2008) Vertical ridge augmentation around implants by e-PTFE titanium- reinforced membrane and bovine bone matrix: a 24- to 54-month study of 10 consecutive cases. Int J Oral Maxillofac Implants 23:858-66. [Crossref]

30. Fontana F, Santoro F, Maiorana C, Iezzi G, Piattelli A, et al. (2008) Clinical and histologic evaluation of allogeneic bone matrix versus autogenous bone chips associated with titanium-reinforced e- PTFE membrane for vertical ridge augmentation: a prospective pilot study. Int J Oral Maxillofac Implants 23:1003-12. [Crossref]

31. Weng D, Poehling S, Pippig S, Bell M, Richter EJ, et al. (2009) The effects of recombinant human growth/differentiation factor-5 (rhGDF-5) on bone regeneration around titanium dental implants in barrier membrane-protected defects: a pilot study in the mandible of beagle dogs. Int J Oral Maxillofac Implants 24:31-7. [Crossref]

32. Leite RS1, Marlow NM, Fernandes JK (2013) Oral health and type 2 diabetes. Am J Med Sci 345: 271-273. [Crossref]

33. Locci P1, Calvitti M, Belcastro S, Pugliese M, Guerra M, et al. (1997) Phenotype expression of gingival fibroblasts cultured on membranes used in guided tissue regeneration. J Periodontol 68: 857-863. [Crossref]

34. Schneider D, Weber FE, Grunder U, Andreoni C, Burkhardt R, et al. (2014) A randomized controlled clinical multicenter trial comparing the clinical and histological performance of a new, modified polylactide-co-glycolide acid membrane to an expanded polytetrafluorethylene membrane in guided bone regeneration procedures Clin Oral Implants Res 25:150-158. [Crossref]

35. Villar CC, Cochran DL (2010) Regeneration of periodontal tissues: guided tissue regeneration. Dental Clinics of North America 54:73-92.

36. Sakallioglu U, Yavuz U, Lutfioglu M, Keskiner I, Acikgoz G (2007) Clinical outcomes of guided tissue regeneration with Atrisorb membrane in the treatment of intrabony defects: a 3-year follow-up study. Int J Periodontics Restorative Dent 27:79-88. [Crossref]

37. Nagarajan S, Reddy B (2009) Bio-absorbable polymers in implantation-An overview. J. Sci. Ind. Res 68:993-1009.

38. Yamada K, Ebihara T, Gondo T, Sakasegawa K, Hirata M (1996) Membrane properties of porous and expanded poly (tetrafluoroethylene) films grafted with hydrophilic monomers and their permeation behavior. Journal of applied polymer science 61:18991912.

39. Diao J-M, Pang X, Qiu Y, Miao Y, Yu M-M, et al. (2015) Construction of a human corneal stromal equivalent with non-transfected human corneal stromal cells and acellular porcine corneal stromata. Exp Eye Res 132:216-224. [Crossref]

40. Buchmann R, Hasilik A, Heinecke A, Lange DE (2001) PMN responses following use of 2 biodegradable GTR membranes. J Clin Periodontol 28: 1050-1057. [Crossref]

41. Stavropoulos A, Kostopoulos L, Mardas N, Nyengaard JR, Karring T (2003) Gentamicin used as an adjunct to GTR. J Clin Periodontol 30: 455-462. [Crossref]
42. Tal H, Kozlovsky A, Nemcovsky C, Moses O (2012) Bioresorbable collagen membranes for guided bone regeneration. INTECH Open Access Publisher.

43. Jang JH1, Castano O, Kim HW (2009) Electrospun materials as potential platforms for bone tissue engineering. Adv Drug Deliv Rev 61: 1065-1083. [Crossref]

44. Mao C, Sato J, Matsuura M, Seto K (1997) Guided tissue regeneration around dental implants in immediate extraction sockets: comparison of resorbable and nonresorbable membranes. Chin Med Sci J. 12:170-174. [Crossref]

45. Zitzmann NU1, Schärer P (1998) Sinus elevation procedures in the resorbed posterior maxilla. Comparison of the crestal and lateral approaches. Oral Surg Oral Med Oral Pathol Oral Radiol Endod 85: 8-17. [Crossref]

46. Kasaj A, Reichert C, Götz H, Röhrig B, Smeets R, et al. (2008) In vitro evaluation of various bioabsorbable and nonresorbable barrier membranes for guided tissue regeneration. Head Face Med. 4:22. [Crossref]

47. Sell SA, McClure MJ, Garg K, Wolfe PS, Bowlin GL (2009) Electrospinning of collagen/biopolymers for regenerative medicine and cardiovascular tissue engineering. Adv Drug Deliv Rev. 61:1007-1019. [Crossref]

48. Ferreira AM, Gentile P, Chiono V, Ciardelli G (2012) Collagen for bone tissue regeneration. Acta Biomater 8: 3191-3200. [Crossref]

49. Sudarsan S, Arun KV, Priya MS, Arun R (2008) Clinical and histological evaluation of alloderm GBR and BioOss in the treatment of Siebert's class I ridge deficiency. $J$ Indian Soc Periodontol 12:73-8. [Crossref]

50. Boymuradov S (2011) MANAGEMENT OF MAXILLARY ALVEOLAR PROCESS FRACTURES BY COMBINATION OF "OSTEON" AND "COLLA GUIDE" RESORBABLE MEMBRANE. Medical and Health Science Journal 5:73-76.

51. Kher VK, Bhongade ML, Shori TD, Kolte AP, Dharamthok SB, et al. (2013) A comparative evaluation of the effectiveness of guided tissue regeneration by using a collagen membrane with or without decalcified freeze-dried bone allograft in the treatment of infrabony defects: A clinical and radiographic study. J Indian Soc Periodontol 17: 484-489. [Crossref]

52. Chi CS, Andrade DB, Kim SG, Solomon CS (2015) Guided tissue regeneration in endodontic surgery by using a bioactive resorbable membrane. J Endod. 41:559-562. [Crossref]

53. Karfeld-Sulzer LS, Ghayor C, Siegenthaler B, Gjoksi B, et al. (2017) Comparative study of NMP-preloaded and dip-loaded membranes for guided bone regeneration of rabbit cranial defects. J Tissue Eng Regen Med 11: 425-433. [Crossref]

54. Ivanovski S, Vaquette C, Gronthos S, Hutmacher DW, Bartold PM (2014) Multiphasic scaffolds for periodontal tissue engineering. J Dent Res 93: 1212-1221. [Crossref]

55. Aurer A, JorgiE-Srdjak K (2005) Membranes for periodontal regeneration. Acta Stomatol Croat 39:107-12.

56. Kim D, Kang T, Gober D, Orlich C (2011) A liquid membrane as a barrier membrane for guided bone regeneration. ISRN Dent 2011: 468282. [Crossref]

57. Liao S, Wang W, Uo M, Ohkawa S, Akasaka T, et al. (2005) A three-layered nanocarbonated hydroxyapatite/collagen/PLGA composite membrane for guided tissue regeneration. Biomaterials 26:7564-7571. [Crossref]

58. Loos BG, Craandijk J, Hoek FJ, Dillen PMW-v, Velden UVD (2000) Elevation of systemic markers related to cardiovascular diseases in the peripheral blood of periodontitis patients. J Periodontol 71:1528-1534. [Crossref]

59. Xue J, He M, Niu Y, Liu H, Crawford A, et al. (2014) Preparation and in vivo efficient anti-infection property of GTR/GBR implant made by metronidazole loaded electrospun polycaprolactone nanofiber membrane. Int J Pharm 475:566-577. [Crossref]

60. Schmidlin PR, English H, Duncan W, Belibasakis GN, Thurnheer T (2014) Antibacterial potential of Manuka honey against three oral bacteria in vitro. Swiss Dent $J$ 124:922-4. [Crossref]

61. Alvarez-Suarez JM, Gasparrini M, Forbes-Hernández TY, Mazzoni L, Giampieri F (2014) The composition and biological activity of honey: A focus on Manuka honey. Foods 3:420-432. [Crossref]

62. Mandal MD, Mandal S (2011) Honey: its medicinal property and antibacterial activity Asian Pac J Trop Biomed 1:154-160. [Crossref]

63. Eick S, Schäfer G, Kwiecinski J, Atrott J, Henle T, et al. (2014) Honey-a potentia agent against Porphyromonas gingivalis: an in vitro study. BMC oral health 14:24 [Crossref]

64. Speer SL, Schreyack GE, Bowlin GL (2015) Manuka Honey: A Tissue Engineering Essential Ingredient. Journal of Tissue Science \& Engineering 2015. 
65. Vallianou NG, Gounari P, Skourtis A, Panagos J, Kazazis C (2014) Honey and its anti-inflammatory, anti- bacterial and anti-oxidant properties. General Medicine: Open Access 2014.

66. Roecken F (2013) Honey in modern wound treatment-the renaissance of an ancient remedy. KLEINTIERPRAXIS 58:617-+.

67. Cooper R (2014) Honey as an effective antimicrobial treatment for chronic wounds: is there a place for it in modern medicine. Chronic Wound Care Management and Research 1:15-22.
68. Tirado DJ, Hudson NR, Maldonado CJ (2014) Efficacy of medical grade honey against multidrug- resistant organisms of operational significance: part I. J Trauma Acute Care Surg 77: S204-S207. [Crossref]

69. Jain A, Bhaskar DJ, Gupta D, Agali C, Gupta V, et al. (2015) Comparative evaluation of honey, chlorhexidine gluconate $(0.2 \%)$ and combination of xylitol and chlorhexidine mouthwash $(0.2 \%)$ on the clinical level of dental plaque: A 30 days randomized control trial. Perspect Clin Res 6:53. [Crossref]

Copyright: (C2018 Rodriguez IA. This is an open-access article distributed under the terms of the Creative Commons Attribution License, which permits unrestricted use, distribution, and reproduction in any medium, provided the original author and source are credited. 